\title{
Synthesis and Performance Properties of Cationic Fabric Softeners Derived from Free Fatty Acid of Tallow Fat
}

\author{
Mithun G. Mondal and Amit Prabhakar Pratap* \\ Department of Oils, Oleochemicals and Surfactant Technology, Institute of Chemical Technology, Matunga, Mumbai, Maharashtra, INDIA
}

\begin{abstract}
Esterquat cationic softener is basically the class of surface active quaternary ammonium compounds. Esterquat compounds were synthesized and their surface behavior, antibacterial activity and Textile softening properties were investigated. Easily found cheap material was used to synthesize cationic fabric softeners. This fabric softener will be a good for commercially and industrially important because their emulsify activity, rewettability dispersing power and softness. Free fatty acids were derived from tallow oil and were treated with triethanolamine and mono-ethanolamine at $140^{\circ} \mathrm{C}$. This diester was quaternaries with dimethyl sulphate and benzyl chloride. The synthesized esterquat compounds were characterized by its cationic content, 1H NMR and FT-IR analysis. In addition to the cationic content, surface tension, CMC (critical micelle concentration), rewettability, fabric softening, emulsification and dispersing power were determined as their surface-active properties. The fabric softening activity of esterquat and esteramide prepared from DMS was better softening activity of fabrics compared to untreated cotton and polyester fabrics cloth. The presented result shows that the esterquat made from $\mathrm{BCl}$ exhibit the best dispersing power. The esterquat made from DMS both in TEA and MEA shows good rewettability was determined.
\end{abstract}

Key words: cationic surfactant, esterification, quaternization, CMC, fabric softening, rewettability, emulsification, dispersing power, antibacterial activity

\section{Introduction}

Esterquat cationic surfactant is the main constituent of a fabric softener composition. This new type of fabric softening agent combines a good environmental profile with the structural features required for an effective fabric conditioner $^{1,2)}$. Esterquat cationic surfactant is one of the biodegradable fabric softener due to the presence of ester linkage $^{3)}$. Specialty of cationic surfactant is environmental friendly, non toxic and biodegradable properties ${ }^{4)}$. Quats have been proven to be useful in variety of application, including the following as fabric conditioner, antistatic agent, biocides, emulsifiers in cosmetics, antibacterial agent, corrosion inhibiters and foam dispersant ${ }^{5)}$. Esterquats are important classes of surfactants that have distinctive qualities that make them attractive for exploration. Esterquats contain a hydrophilic polar "head" -OH group, and a hydrophobic alkyl chain "tail" ${ }^{\text {) }}$. They are absorbed on the surface of fabric with their hydrophobic group oriented away from the fabric. Surfactant reduces the friction between fibbers and imparts a soft, fluffy feel to the fabric ${ }^{7)}$.

In this paper, we report on the synthesis of cationic surfactant derived from esterification of tri and mono-ethanolamine with free fatty acid of tallow oils. This fatty ester reacts with an alkylating agent like dimethyl sulfate and benzyl chloride to form corresponding quaternary compound ${ }^{8)}$. The obtained product in each case was characterized by its cationic content and structure was confirmed by 1H NMR and FT-IR analysis. Each surfactant surface active property can be measure in a variety of ways and the method of choice often depends on the characteristics of the substance to be analysis. The most frequently determined properties probably are surface tension and critical micelle concentration.

\footnotetext{
*Correspondence to: Amit Prabhakar Pratap, Department of Oils, Oleochemicals and Surfactant Technology, Institute of Chemical Technology, Matunga, Mumbai, Maharashtra, INDIA

E-mail: amitpratap0101@ rediffmail.com

Accepted April 9, 2016 (received for review November 30, 2015)

Journal of Oleo Science ISSN 1345-8957 print / ISSN 1347-3352 online

http://www.jstage.jst.go.jp/browse/jos/ http://mc.manusriptcentral.com/jjocs
} 


\section{Materials and method}

\subsection{Materials for Synthesis of Esteramide Quates}

The reagent used in synthesis of diester and esterquat were purchased from Sigma Aldrich Pvt. Ltd, India while toluene, diethyl ether, hexane and various other solvents used were purchased from Thomas baker's Pvt. Ltd. Mumbai, India.

Fabrics for evaluation of softening and rewettability, i.e. $100 \%$ cotton and $100 \%$ polyester were obtained from the market.

\subsection{Experimental}

2.2.1 Synthesis of diester from tallow free fatty acid

The reaction for the synthesis of diester esterquat(Fig.
1) was obtained from fatty acid with triethanolamine. The diester was prepared by a triethanolamine with fatty acid, followed by reaction with an alkylation agent to the corresponding quaternary. In the presence of a catalyst orthophosphoric acid the ( 2 mole) of fatty acid and ( 1 mole) of triethanolamine was heated up to temperature $160-170^{\circ} \mathrm{C}$ to obtain high conversion and water removal is enhanced by striping with an inert gas. The reaction times vary from 8-10 hours and the reaction was monitor by acid values. The acid value was checked after half an hour. The reaction was continued until acid value reached 6.0.Similarly, the reaction for the preparation of ester amide of monoethanolamine with free fatty acid of tallow fat.

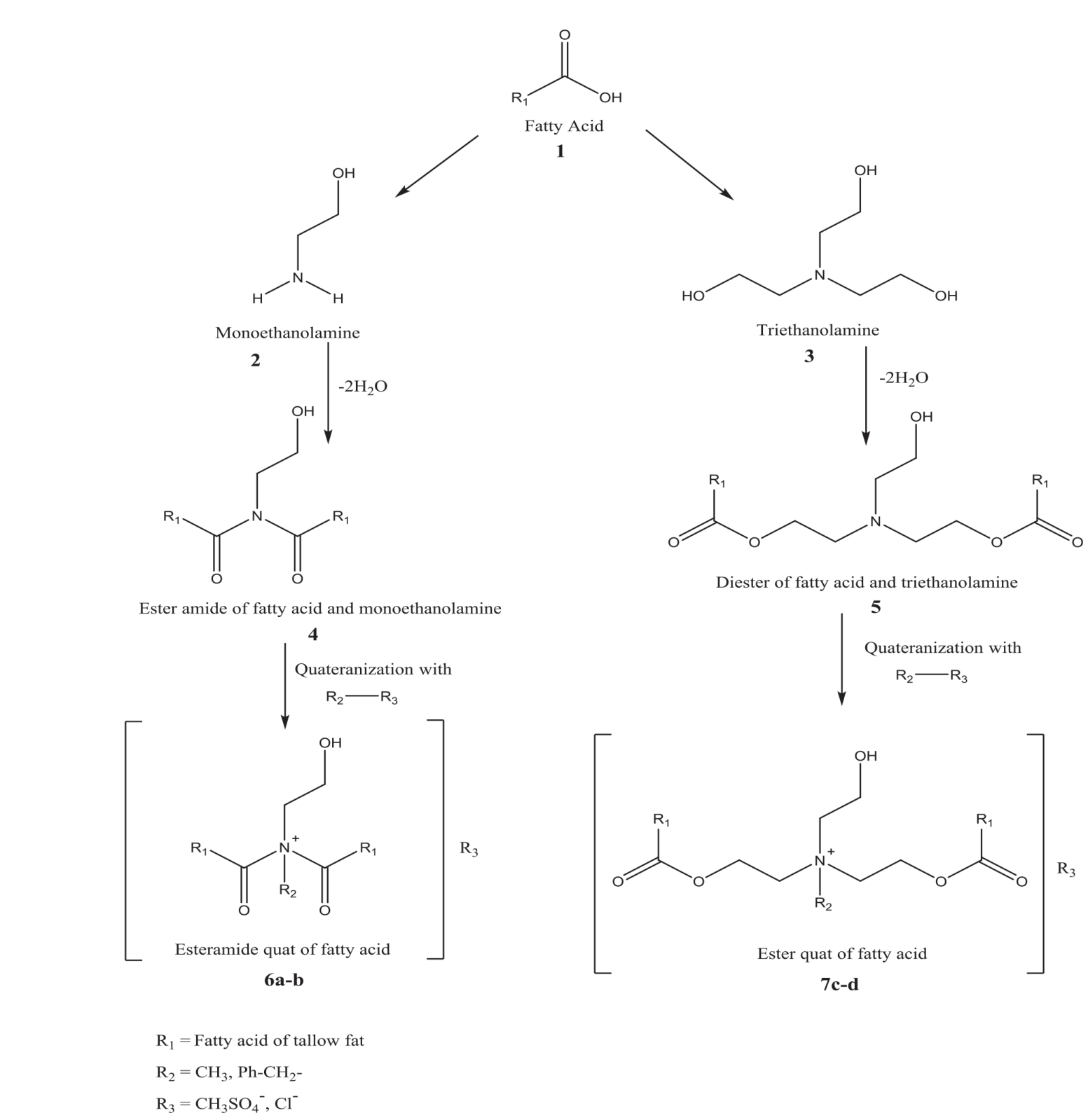

Fig. 1 Synthesis of esteramide and esterquats. 


\section{Synthesis and Performance Properties of Cationic Fabric Softeners}

\subsubsection{Quaternerization of Esterquats}

The free fatty acid of diester and esteramide is reacted with an alkylation agent like dimethyl sulphate, benzyl chloride, to obtained corresponding quaternary ammonium compound(Fig. 1). For this 1 mole of di-ester of tri-ethanolamine was dissolve in petroleum ether in $250 \mathrm{~mL}$ of round bottom flask. Thermometer was inserted in one neck of flask and condenser was fitted on the other neck. When the di-ester was completely dissolved in it, then 1.5 mole of alkylating agent was added drop by drop with constant starring for 2 hours at $65-70^{\circ} \mathrm{C}$. Esterquats were transferred to a beaker and the petroleum ether was evaporated on water bath until a viscous compound was obtained.

Similarly the esterquat of monoethanolamine was prepared by using alkylating agent like dimethyl sulphate, benzyl chloride, to obtained corresponding quaternary ammonium compound (Fig. 1).

\section{Characterization of esterquat and Esteramide Quat 3.1 Determination of Cationic Content ${ }^{9,10)}$ :}

The cationic content of esteramide and esterquats was determined using the method describe in BIS: 4955 (1978) p 8.

Reagent

1. Chloroform

2. 0.004 M Sodium Lauryl Sulphate Solution

$1.464 \mathrm{~g}$ of sodium Lauryl sulphate was dissolve in $1000 \mathrm{ml}$ of distilled water to make $0.004 \mathrm{M}$ solution.

3. $0.003 \%$ Methylene Blue Solution

$0.003 \mathrm{~g}$ of Methylene blue, $30 \mathrm{~g}$ of sodium sulphate and $4.1 \mathrm{~mL}$ of concentrated sulphuric acid were taken in distilled water and diluted to $1000 \mathrm{ml}$ with distilled water.

4. 0.004 M Esterquat Solution

Adequate quantity of esterquat was weighed and dissolved in 20-30 $\mathrm{mL}$ of ethanol and made the volume up to $250 \mathrm{~mL}$ distilled water.

Procedure

$10 \mathrm{~mL}$ of standard cationic surfactant solution (esterquats, esteramide) was taken in $250 \mathrm{~mL}$ stopper flask and add $15 \mathrm{~mL}$ chloroform and $25 \mathrm{~mL}$ of methylene blue solution to the cylinder and shake well. After gentle shaking, flask was allowed to stand until the two layer separated. The organic layer was blue colored. It was then titrated against $0.004 \mathrm{M}$ solution of sodium lauryl sulphate. Towards the end point the colour would start migrating to the aqueous layer. The reading was noted down when the same colour intensity in both the phase was observed. Cationic content was measured as follows:

Molarity of esterquat $\mathrm{M}_{1}=10 \mathrm{M}_{2} / \mathrm{V}_{1}$
Where,

$$
\begin{aligned}
& M_{1}=\text { Molarity of esterquat } \\
& M_{2}=\text { Molarity of sodium lauryl sulphate } \\
& V_{1}=\text { Used volume for esterquat }
\end{aligned}
$$$$
\text { Cationic content }=\frac{\mathrm{M}_{1} \text { XmolweightofesterquatX } 100}{\text { weightofsampleX4 }}
$$

\subsection{Determination of $\mathrm{cmc},{ }^{\gamma} \mathrm{cmc}$}

The surface tensions of aqueous of the esterquats were measured with a Kruss K11 tension tenstiometer with the help of a Wilhelmy plate made up of platinum. Measurement were taken at $25 \pm 1^{\circ} \mathrm{C}$. The surfactant solution was added to water in a thermos tatted glass vessel by using a micro syring. CMC and surface tension at CMC were determined from the breakpoint of the surface tension of their aqueous solution versus concentration.

\subsection{Emulsibilty}

The emulsibilty of the synthesized cationic surfactant was determined using $10 \mathrm{ml}$ of $1 \%$ aqueous solution of surfactants and $5 \mathrm{~mL}$ of toluene at $40^{\circ} \mathrm{C}$. The mixed liquid was stirred by homogenizer for $1 \mathrm{~min}$ and the emulsion was formed. The emulsion was poured into a measuring cylinder, and the time was recorded when as the time of separation of water $(9 \mathrm{~mL})$ from the emulsion layer ${ }^{11)}$.

\subsection{Dispersing power}

Dispersing power of the prepared esterquats was determined using $\mathrm{TiO}_{2}$ and $1 \%$ surfactant solution. The surfactant solution with $\mathrm{TiO}_{2}$ were shaken and allowed to stand. Dispersing power was carried out by looking at the height and cloudiness of surfactant solution and recorded the scores $^{12)}$.

\subsection{Softening power}

A 'feel' test panel to determine the softeners was applied, based on the panel feel test ${ }^{13,14)}$. The treated and non-treated, cloth were to the trained panelist with the requirement to judge which cloth of the pair is softer. The softening rating of different substrate decided by average grade obtained from panelist, better softer has higher grade given in Table 6.

\subsection{Rewettability}

The dye wick-up method ${ }^{15)}$ was used to measuring the rewet of treated fabric with the investigated softening formulation $^{16)}$. Initially, the standard fabric were treated the same way as in above-mentioned softening method. Then the fabric were hung vertically and dipped in a $0.2 \mathrm{wt} \%$ telon blue RR acid dye solution, where the immersion depth was $2 \mathrm{~cm}$. A stopwatch was started as soon as the strip was fabric strip was dipped. The distance of dye separation was measured in centimeter at $5 \mathrm{~min}$, as the height of wetted cationic treated fabrics. Table 5 shows rewetta- 
bility data of different treated fabric with different surfactant solution.

\subsection{Instrumental Analysis}

The structures of compounds were determined by means of spectral analysis: $1 \mathrm{H}$ NMR and FT-IR. FT-IR spectra were obtained by using a model Miracle 10.DRS plate of the sample was subjected to analysis with 30 scan. NMR spectra were recorded with a Bruker avance DRX-500 in $\mathrm{CDCl}_{3}$ solution.

\section{Results and Discussion}

\subsection{Characteristics of Experimental Fatty Acids}

The acid value, saponification value, appearance and melting point of free fatty acid of tallow are in Table 1. The acid value determined was 174.03 . The saponification value and melting point were found to be in normal range as expected.

\subsection{Synthesis of Diester}

Fatty esters are generally prepared by the reaction of an acid with a different alcohol like triethanolamine and mono ethanolamine. Cationic surfactant constitutes an important class of fabric softener. The aim of research was to synthesize better surfactant from easily available chiefly fatty acid like tallow, which should be better quality and yield of product. The esterquat was prepared by two steps, the product obtained from the first step, which involved ester formation from free fatty acid and alcoholic amine like mono and triethanolamine. In etherification reaction the lowest acid value of product was obtained. The acid value of condensate product(Diester formation) reduces rapidly because water of condensation being removed from

Table 1 Characteristics of tallow fat.

\begin{tabular}{cc}
\hline Characteristics & Value \\
\hline Saponification value & 186.122 \\
Acid value & 174.03 \\
Melting point & $>40^{\circ} \mathrm{C}$ \\
Appearance & Off-white, solid fat \\
\hline
\end{tabular}

mixture at $150^{\circ} \mathrm{C}$. In the presence of catalyst Orthophosphoric acid was found yield for this reaction. The lowest acid value (5.5) of diester was obtained at $170^{\circ} \mathrm{C}$ with Orthophosphoric acid as a catalyst. The diester derived from free fatty acid gave a maximum yield was carried out at $170^{\circ} \mathrm{C}$. The reaction was controlled by monitoring the acid value during the synthesis.

\subsection{Synthesis of Esterquats}

Table 2 shows the yield percentage yields by weight and cationic content of different di-esterquats, prepared by quaternization of diester and ester amide by DMS and Benzyl chloride. The quaternization was carried out at a $70-80^{\circ} \mathrm{C}$ for 2 hours and cationic matter for each product was determined. The result shows that quaternization of diester for 2 hours using 1:1.5 molar ratio of diester to different halide group give better yield of esterquat. Quaternization time also had an important role in the cationic content of esterquats. Increasing the duration of quaternization did not increase the cationic content. The solubility test indicates that esterquat was soluble in both cold and warm water. The reason is that esteramide and esterquats surfactant molecule present polar alcoholic group. Because polar group increasing solubility due to hydrogen bonding. The $\mathrm{O}-\mathrm{H}$ bond is not only polar but is also able to form hydrogen bond with water molecule as well as each other.

\subsection{H NMR}

Spectral data of Esteramide and Esterquats surfactant are as follow:

1) 6a- Esteramide of dimethyl sulphate

$1 \mathrm{H} \mathrm{NMR}(500 \mathrm{MHz} \mathrm{CDCl} 3): \delta$ 0.86-1.99[99 H, m, $\left(-\mathrm{CH}_{2}{ }^{-}\right.$ $\left.\left(\mathrm{CH}_{2}\right)_{\mathrm{n}}-\mathrm{CH}_{2^{-}}\right)$Aliphatic chain $]$; 2.66-2.33[8 H, d t, $\left(-\mathrm{CH}_{2}-\mathrm{C}\right.$ $\left.\left.=\mathrm{O},-\mathrm{N}-\mathrm{CH}_{2}-\mathrm{CH}_{2}{ }^{-}\right)\right]$; 3.64[3 H, s, ( + N-CH $\mathbf{H}_{3}$ sulphate $\left.)\right]$; $5.32\left[3 \mathrm{H}, \mathrm{s},\left(-\mathrm{CH}_{3} \mathrm{SO}_{4}^{-}\right)\right]$

2) 6b- Esteramide of benzyl chloride

$1 \mathrm{H} \mathrm{NMR}(500 \mathrm{MHz} \mathrm{CDCl} 3): \delta$ 0.87-1.25[83 H, m, $\left(-\mathrm{CH}_{2}-\right.$ $\left.\left(\mathrm{CH}_{2}\right)_{\mathrm{n}}-\mathrm{CH}_{2^{-}}\right)$Aliphatic chain $] ;$2.01-2.0[6 H, t, $\left(-\mathrm{CH}_{2}-\mathrm{CH}_{2}{ }^{-}\right.$ $\mathrm{C}=\mathrm{O})] ;$ 2.37-2.33 [8 H, $\left.\left(-\mathrm{CH}_{2}-\mathrm{C}=\mathrm{O}\right),-\mathrm{CH}_{2}-\mathrm{OH}\right] ; 5.33-5.36$ $\left[4 \mathrm{H}, \mathrm{m},\left(-\mathrm{CH}_{2}-\mathrm{N}+\right.\right.$ Benzyl $\left.),\left(-\mathrm{CH}_{2}-\mathrm{OH}\right)\right] ; 7.26[5 \mathrm{H}, \mathrm{m}$, (Aromatic C-H)].

3) 7c- Esterquats of dimethyl sulphate

$1 \mathrm{H}$ NMR (500 MHz CDCl3) : $\delta$ 0.85-2.35[288 H, m, $\left(-\mathrm{CH}_{2^{-}}\right.$

Table 2 Reaction parameters of different quats derived from tallow fatty acid.

\begin{tabular}{cccccc}
\hline Surfactant & $\begin{array}{c}\text { Diester: } \\
\text { Alkyl halide }\end{array}$ & Molar Ratio & Time (h) & $\begin{array}{c}\text { Cationic } \\
\text { Content }(\%)\end{array}$ & Yield (\%) \\
\hline 6a & $4: \mathrm{DMS}$ & $1: 1.5$ & $2 \mathrm{~h}$ & 71.03 & 90 \\
$6 \mathrm{~b}$ & $4: \mathrm{BCl}$ & $1: 1.5$ & $2 \mathrm{~h}$ & 58.9 & 85 \\
$7 \mathrm{c}$ & $5: \mathrm{DMS}$ & $1: 1.5$ & $2 \mathrm{~h}$ & 70.0 & 89 \\
$7 \mathrm{~d}$ & $5: \mathrm{BCl}$ & $1: 1.5$ & $2 \mathrm{~h}$ & 63.7 & 87 \\
\hline
\end{tabular}


$\left.\left(\mathrm{CH}_{2}\right)_{\mathrm{n}}-\mathrm{CH}_{2^{-}}\right)$Aliphatic chain]; 3.65[3 H, s, ( + N-CH $\left.\mathbf{H}_{3}\right)-$ sulphate) $]$; 4.4-4.17[4 H, t, $\left.2\left(-\mathrm{O}-\mathrm{CH}_{2}-\mathrm{CH}_{2}\right)\right]$; 5.30-5.37[10 $\mathrm{H}, \mathrm{m}, 2\left(-\mathrm{CH}_{2}-\mathrm{C}=\mathrm{O}\right), 2\left(+\mathrm{N}-\mathrm{CH}_{2}-\mathrm{CH}_{2}-\mathrm{O}-\mathrm{C}=\mathrm{O}\right),\left(+\mathrm{N}-\mathrm{CH}_{2}-\right.$ $\left.\left.\mathrm{CH}_{2}-\mathrm{OH}\right)\right] ; 5.79\left[3 \mathrm{H}, \mathrm{s},\left(-\mathrm{CH}_{3} \mathrm{SO}_{4}^{-}\right)\right]$.

4) $7 \mathrm{~d}$ - Esterquats of benzyl chloride

$1 \mathrm{H} \mathrm{NMR}(500 \mathrm{MHz} \mathrm{CDCl} 3): \delta$ 0.86-2.36[80 H, m, $\left(-\mathrm{CH}_{2}{ }^{-}\right.$ $\left.\left(\mathrm{CH}_{2}\right)_{\mathrm{n}}-\mathrm{CH}_{2^{-}}\right)$Aliphatic chain]; 4.44-3.51[13 H, dt, 2(-O$\left.\left.\mathrm{CH}_{2}-\mathrm{CH}_{2}-\mathrm{N}+\right),\left(+\mathrm{N}-\mathrm{CH}_{2}-\mathrm{CH}_{2}-\mathrm{OH}\right)\right] ; 5.34-5.76[5 \mathrm{H}, \mathrm{m}$, (Aromatic C-H)].

\subsection{FT-IR}

Diester and esteramide: The FT-IR data obtained for diester and ester amide is tabulated in Table 3. The forma- tion of diester was confirmed by The $\mathrm{OH}$ starching vibration and deformation was indicated by the peak at 3340.71 and $\sim 1076.28 \mathrm{~cm}^{-1}$ respectively. The C-N stretching at $\sim 1068 \mathrm{~cm}^{-1}$ (amide group), $\mathrm{C}=\mathrm{O}$ stretching (amide group) at $\sim 1641.42 \mathrm{~cm}^{-1}, \mathrm{C}=\mathrm{O}$ stretching (ester group) at $1737.86 \mathrm{~cm}^{-1}$.

Esterquats: FT-IR spectra of esterquat shows similar type of peak as those in the spectra of diester and ester amide, except for the peak of $\mathrm{S}=\mathrm{O}$ stretching (DMS group) at $\sim 100.91 \mathrm{~cm}^{-1}$ and $\sim 707.8 \mathrm{~cm}^{-1}$ for benzene ring of (aromatic ring). Presence of quaternary $\mathrm{N}^{+}$was confirmed by the peak obtained at $\sim 1462.04 \mathrm{~cm}^{-1}$. Instrumental analysis of diester, esteramide and esterquats is shown in Table 3

Table 3 Interpretation of IR spectrum.

\begin{tabular}{lcccc}
\hline Group & $\begin{array}{c}\text { Diester of } \\
\text { Triethanolamine } \\
\left(\mathrm{cm}^{-1}\right)\end{array}$ & $\begin{array}{c}\text { Esteramide of } \\
\text { Monoethanolamine } \\
4\left(\mathrm{~cm}^{-1}\right)\end{array}$ & $\begin{array}{c}\text { Esteramide 6a-b } \\
\left(\mathrm{cm}^{-1}\right)\end{array}$ & $\begin{array}{c}\text { Esterquat 7c-d } \\
\left(\mathrm{cm}^{-1}\right)\end{array}$ \\
\hline O-H stretching & 3340.71 & 3379.29 & $\sim 3388.93$ & $\sim 3379.29$ \\
O-H Deformation & 1076.26 & 1050 & $\sim 1053.13$ & $\sim 1068.56$ \\
$\mathrm{C}=\mathrm{O}$ & 1737.86 & & $\sim 1739.79$ & $\sim 1639.49$ \\
$\mathrm{C}-\mathrm{O}$ & 1168.86 & 1124.5 & $\sim 1197.79$ & $\sim 1124.5$ \\
Tertiary N & $2850.79,1566.2$ & 2852.72 & $\sim 2854.65$ & $\sim 2852.72$ \\
$\mathrm{~S}=\mathrm{O}$ & & & 1006.84 & 1068.56 \\
$\mathrm{CH}{ }_{2}$ & 2918.3 & 2924.09 & $\sim 2922.16$ & $\sim 2924.09$ \\
Mono substituted benzene ring & & & 756.1 & $727.16,702.09$ \\
Quaternary $\mathrm{N}^{+}$ & & & 1456.26 & 1454.33 \\
\hline
\end{tabular}

Where,

4- Esteramide of monoethanolamine, 5-Diester of triethanolamine

6a- Esteramide of dimethyl sulphate, 6b- Esteramide of benzyl chloride.

7c- Esterquats of dimethyl sulphate, 7d- Esterquats of benzyl chloride.

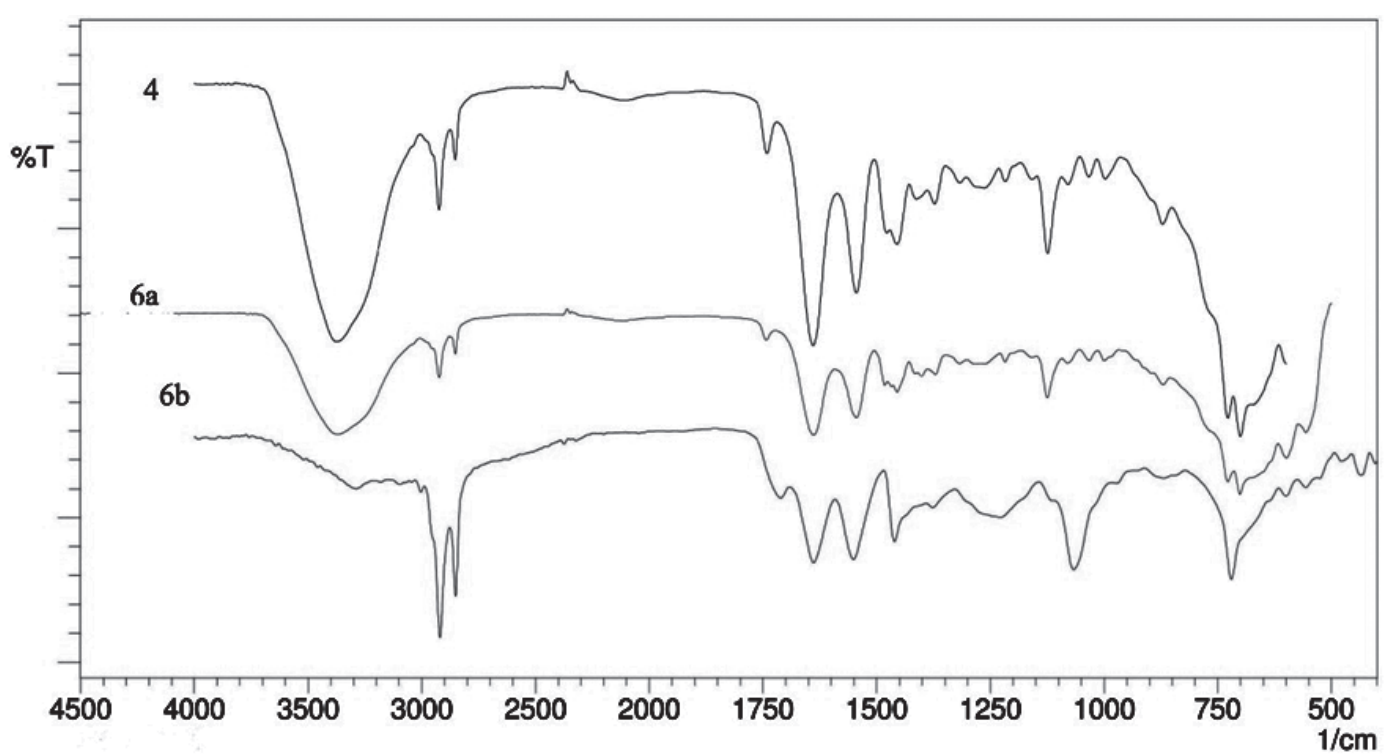

Fig. 2 FTIR spectrogram of esteramide quates. 


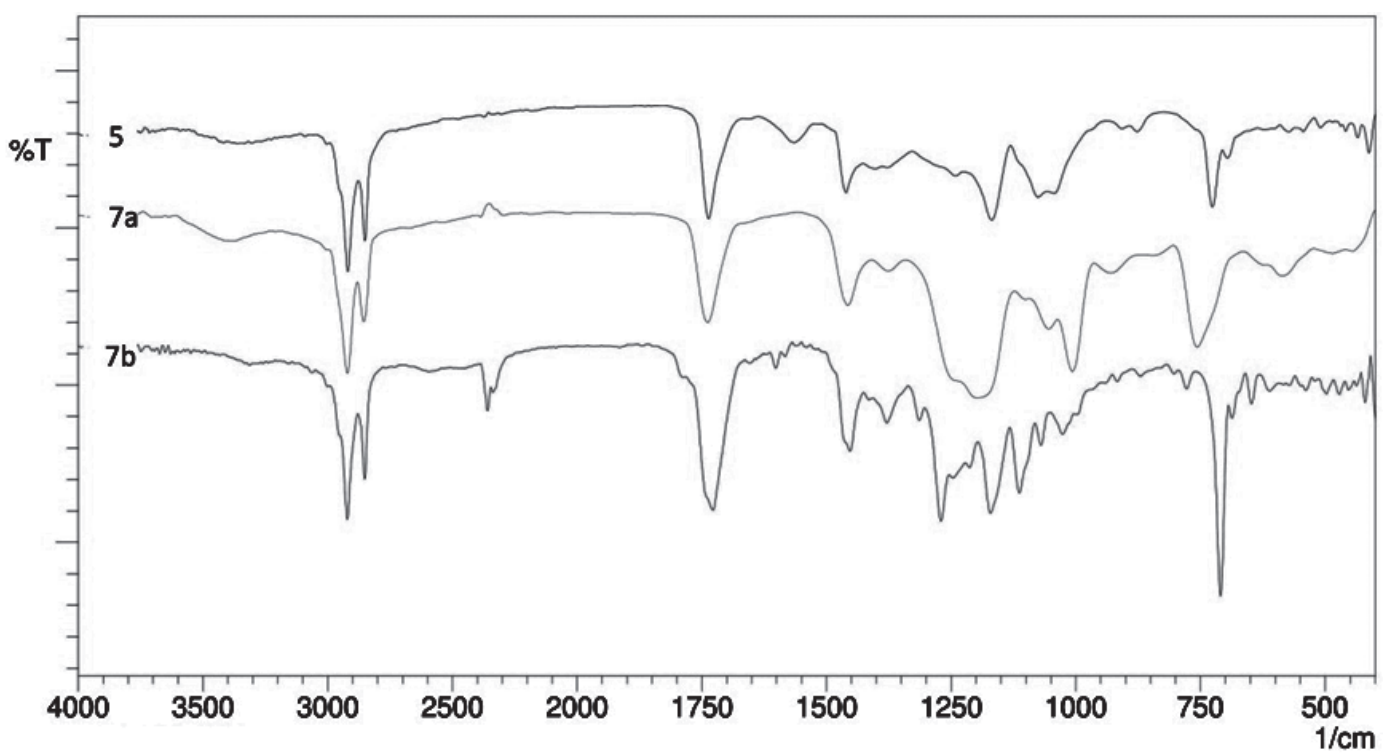

Fig. 3 FTIR spectrogram of esterquat.

Table 4 Surface active properties of different esterquat and esteramide quats derived from tallow fatty acid and TEA and MEA.

\begin{tabular}{ccccccc}
\hline Surfactant & $\begin{array}{c}\text { Surface } \\
\text { Tension } \mathrm{mN} / \mathrm{m}\end{array}$ & $\begin{array}{c}\mathrm{CMC} \\
(\mathrm{mmol} / \mathrm{L})\end{array}$ & $\begin{array}{c}\text { Cationic } \\
\text { content }(\%)\end{array}$ & $\begin{array}{c}\text { Emulsion } \\
\text { stability }(\mathrm{min})\end{array}$ & $\begin{array}{c}\text { Dispersing power } \\
\left(\mathrm{TiO}_{2}\right)(\text { vol. in } \mathrm{ml})\end{array}$ & $\begin{array}{c}\text { Average molar } \\
\text { mass }(\mathrm{g} / \mathrm{mole})\end{array}$ \\
\hline $6 \mathrm{a}$ & 30.89 & 0.046 & 71.03 & $55 \mathrm{~min}$ & 6.5 & 1082 \\
$6 \mathrm{~b}$ & 27.81 & 0.002 & 58.9 & $40 \mathrm{~min}$ & 10 & 1096 \\
$7 \mathrm{c}$ & 32.54 & 0.158 & 70.0 & $57 \mathrm{~min}$ & 8 & 883 \\
$7 \mathrm{~d}$ & 29.00 & 0.246 & 63.7 & $42 \mathrm{~min}$ & 10 & 897 \\
\hline
\end{tabular}

and graphs are shown in Figs. 2 and 3.

\subsection{Surface Tension}

After the synthesis of tallow based esterquat, we further investigated their surface active properties Critical micelle concentration $(\mathrm{CMC})$ values, surface tension at $\mathrm{CMC}\left({ }^{\gamma} \mathrm{cmc}\right)$ are summarized in Table 4. In general the critical micelle concentration indicate the concentration at which the surfactant start to aggregate into micelles. Table 4 indicates that surface tension of all the esterquat good range that is below $30 \mathrm{mN} / \mathrm{m}$. The $\mathrm{CMC}$ value was calculated by the plate methods shown in Table 4 . The tallow based esterquat and esteramide surfactant CMC value decreases or increases depend their central nitrogen atom of tri-ethanolamine, mono-ethanolamine and polar alkyl halide group like dimethyl sulfate and benzyl chloride. Because of large head group expected aggregate structure was spherical in shape $^{17)}$.

\subsection{Emulsion Stability}

Emulsification is defined suspension of liquid droplets (dispersed phase) of a certain size within a second immiscible liquid (continuous phase). The main action of emul- sion is reduced the interfacial tension between the phases and forming the barrier between the phases. Hence, a surfactant, mostly termed emulsifier, is necessary for stabilization. Esterquats and esteramide quates showed good emulsion stability. Table 4 shows that emulsion stability was different in different surfactant depends their size and alkylating agent. The experimental data a show that esterquat derived from DMS has best emulsion stability while esterquat derived from benzyl chloride has lower emulsion stability.

\subsection{Dispersing Power}

Increased length of the alkyl chain increases degree of dispersing power. The dispersion of carbon in aliphatic hydrocarbon is raised by the addition of alkyl benzene. The benzene ring is presumably adsorbed onto the surface of the carbon and the alkyl chain length increases the stability of dispersion liquid. Increases in the length and alkyl group to the benzene nucleus increases the stability of disper$\operatorname{sion}^{18)}$. The resulting data shown in Table 4 indicate that the esterquat and esteramide quates prepared from benzyl chloride exhibit the best dispersing power in comparison to prepared from DMS. 
Table 5 Result of fabric rewettability using different concentration of surfactant solutions.

\begin{tabular}{ccccccc}
\hline Surfactant & $\begin{array}{c}\text { Rewetting } \\
(\mathrm{cm}) \\
100 \% \text { cotton }\end{array}$ & & $\begin{array}{c}100 \% \\
\text { polyester }\end{array}$ & & $\begin{array}{c}\text { Untreated } \\
\text { cotton }\end{array}$ & $\begin{array}{c}\text { Untreated } \\
\text { polyester }\end{array}$ \\
\hline 6a & 0.1 & 1.0 & 0.1 & 1.0 & 2.5 & 2.0 \\
6b & 4 & 4.1 & 1.2 & 1.3 & & \\
$7 \mathrm{c}$ & 3.7 & 2.9 & 0.5 & 2.0 & \\
$7 \mathrm{~d}$ & 4.5 & 5.5 & 5.0 & 3.0 & \\
\hline
\end{tabular}

${ }^{a}$ Dye migration after $5 \min ($ in $\mathrm{cm}$ )

\subsection{Rewettability}

Surface activity of water is an important aspect for detergency, water proofing, dying water absorption. An important role of wetting agent is minimizing the both surface tension of surfactant solution and its interfacial tension against the solid ${ }^{19)}$. The dye-wick method measure the water absorbency characteristics of fabrics treated with softener. Better water absorbency is important for a treated cloth, because fabrics softener can change water absorptivity of the treated textile. The absorbency rule the increases the softener on a fabrics decreases its water absorbency or increasing the softening activity decreases water absorbency ${ }^{20)}$. It can show Table 5, that after test with the investigated softeners, rewettability of all the cotton and polyester fabric sample decreasing trend. As the rewettability of treated fabrics, $100 \%$ cotton shows good migration than $100 \%$ polyester. Similarly the both untreated fabrics like cotton and polyester tested, it shows that the rewettability activity poorest than treated fabrics. Esterquats made from DMS both TEA and MEA good rewettability was determined.

\subsection{Softening}

The most cationic surfactant is used to improved fabrics softeners ${ }^{21}$. We had evaluated the softness property by panel feel test where the softness have been qualitatively assessed and rating has been given in terms of one to five (+) symbols indicating poor to excellent softness property subsequently. Their activity depends on the use in fatty alkyl chain and quaternerizing group. It was observed from Table 6 that esterquat and esteramide preparation from DMS was better softening activity on fabrics. In both esteramide quates and di-esterquats shows better softening so we can use commercially fabrics softeners.

\section{Conclusions}

Free fatty acids were derived from tallow fat and react with TEA and MEA at $150-160^{\circ} \mathrm{C}$. It was compared with the
Table 6 Comparable result of softening property of 1\% aqueous solution of esterquat ${ }^{13,14)}$.

\begin{tabular}{ccc}
\hline Surfactant & $100 \%$ cotton & $100 \%$ polyester \\
\hline $6 \mathrm{a}$ & ++++ & +++ \\
$6 \mathrm{~b}$ & +++ & ++ \\
$7 \mathrm{c}$ & ++++ & +++ \\
$7 \mathrm{~d}$ & + & + \\
kaosoft agl 85 & ++++ & ++++ \\
(commercial grade) & + & \\
\hline
\end{tabular}

kaosoft agl85 (commercial grade) fabric softener with synthesized cationic surfactant. It was found that our fabric cationic surfactant has less softening activity than kaosoft ag185 (commercial grade) surfactants. It was observed that esterquat and esteramide preparation from DMS was better softening activity on fabrics than Benzyl chloride. This fabric softener will be a good for commercially and industrially important because their emulsify activity, rewettability dispersing power and softness. The presented result shows that the esterquat made from benzyl chloride exhibit the best dispersing power. The esterquat made from DMS both in TEA and MEA shows good rewettability was determined. The fabric softening activity of esterquat and esteramide prepared from DMS was better softening activity of fabrics compared to untreated cotton and polyester fabrics cloth.

\section{Acknowledgement}

The authors gratefully acknowledge the university grant commission (UGC-Green Tech.) of India for providing special assistance program (SAP) fellows.

\section{Supporting Information}

This material is available free of charge via the Internet 
at http://dx.doi.org/jos.64.10.5650/jos.ess.15276

\section{References}

1) Mishra, S.; Tyagi, V. K. Esterquats: the novel class of cationic fabric softeners. J. Oleo Sci. 56, 269-276 (2007).

2) Geng, T.; Li, Q. X. M; Jiang, Y. J.; Wang, W. Esterification of stearic acid with triethanolamine over zirconium sulfate supported on SBA-15 mesoporous molecular sieve. J. Surfact. Deterg. 14, 15-22 (2011).

3) Guo, X. F.; Jia, L. H. Synthesis and application of cationic surfactant. Chemical Industry press, Beijing (2003).

4) Baker, J. A.; Willing, R. I.; Furlong, D. N. Sugar fatty acid ester surfactants: biodegradation pathways. $J$. Surfact. Deterg. 3, 13-27 (2000).

5) Greek, B. F. Sales of detergent growing despite recession. Hem. Eng. News 69, 25-52(1991).

6) Ward, H. L. Textile softeners for home laundering. $J$. Home Econ. 49, 122-123 (1992).

7) Mcnally. J. P.; Mccord, F. A. Cotton quality study: V: resistance to abrasion. Text. Res. J. 30, 715-751 (1960).

8) Trius, A.; Hubert, M.; Bigorra, J.; Cuadrado, F.; Pomares, J. Patent WO1991001295.

9) Bureau of Indian Standard: 548(Part I), p. 29 (1964).

10) Tyagi, R.; Tyagi, V. K.; Khanna, R. K. Synthesis, characterization and performance of tallow fatty acids and triethanolamine based esterquats. J. Oleo Sci. 55, 337-345 (2006).

11) Mishra, S.; Tyagi, V. K. Synthesis and characterization of palm fatty acid and 1(2-hydroxyetyl piperazine) based cationic fabric softeners. Surf. Rev. Lett. 14, 1129-1134(2007).

12) Hoffman, K. The chemistry of heterocyclic compound. Interscience Publishers Inc., New York, pp. 213-226 (1953).

13) Egan, R. R. Cationic surface active agents as fabric softeners. J. Am. Oil Chem. Soc. 55, 118-121 (1978).

14) Mishra, S.; Tyagi, V. K. Synthesis and performance properties $\mathrm{f}$ cationic fabric softeners derived from different fatty acids and 1(2-hydroxyethylpiperazine). $J$. Surfact. Deterg. 11, 167-173(2008).

15) Ginn, M. E.; Schenach, T. A.; Jungermann, E. Performance evaluation of selected fabric softeners. J. Am. Oil Chem. Soc. 42, 1084-1088(1965).

16) Bahmaei, M.; Badiee, F.; Kasehgari, H. Synthesis, IR, HPLC analysis and performances of palm fatty acids and triethanolamine-based esterquats. J. Surfact. Deterg. 14, 173-177 (2011).

17) Nagarajun, R. Molecular packing parameter and surfactant self-assembly: The neglected role of the surfactant tail. Langmuir 18, 31-38(2002).

18) Milton, J. Surfactant and Interfacial Phenomena $3^{\text {rd }}$ ed. Rosen Surfactant Research Institute Brooklyn College the City University of New York (2004).

19) Cutler, W. G.; Davis, R. C. Detergency Theory and Test Method. Surfactant Science Series, Vol. 5: Marcel Dekker Inc. New York (1981).

20) Egan, R. R. Cationic surface active agents as fabric softeners. J. Am. Oil Chem. Soc. 55, 118-121 (1978).

21) Richmond, J. M. Cationic surfactant. Surfactant Science Series Vol. 34, Marcel Dekker Inc. Barcelona(in Spain) (1996). 